\title{
Mobil Uygulamalarda Oyunlaştırma Kabulünün Tüketicilerin Tutumuna ve Kullanım Niyetlerine Olan Etkisinin Belirlenmesi
}

\section{Bahman Huseynli ${ }^{1} \odot$}

\author{
Zehra Bozbay ${ }^{2} \odot$
}

\section{Öz}

Dünyada ve Türkiye'de mobil cihazların kullanımının artması ile birlikte işletmelerin mobil cihazlarla müşterilerine her yerde ve her an ulaşmaları mümkün hale gelmiştir. Bu amaçla, işletmeler tarafindan mobil uygulamalar hazırlanıp tüketicilerin hizmetine sunulmaktadır. Günümüzde, mobil uygulamalarda kullanılan özelliklerden biri de kullanımı hızla artan oyunlaştırmadır. Oyunlaştırma, satışları ve müşteri bağ|ıı̆ını artırmak için yenilikçi uygulamalarla yeni bir iş stratejisi olarak ortaya çıkmaktadır. Oyunlaştırma ile oyun temelli uygulamaların kullanılması tüketicilerin olumlu deneyim yaşamalarını sağlamaya yardımcı olmaktadır. Oyunlaştırmanın tüketicilere keyifli deneyim sağladığı ve bağıııklarını arttırdığı göz önüne alındığında oyunlaştırmanın tüketici satın alma davranışı üzerindeki etkisinin incelenmesi önemlidir. Çalışmanın amacı, mobil uygulamalardaki oyunlaştırmanın kabulünün tüketicilerin tutumlarına ve kullanım niyetlerine olan etkisinin belirlenmesidir. Çalışmanın sonucunda mobil uygulamalardaki oyunlaştırmanın kabulünün tüketicilerin tutumunu ve kullanım niyetlerini etkilediği saptanmıştr.

\section{Anahtar Kelimeler \\ Oyunlaştırma • Mobil uygulamalar • Tutum • Kullanım niyeti • Oyunlaştırma kabulü}

\section{The Effect of Gamification Adoption in Mobile Applications on Consumers' Attitude and Use Intention}

\section{Abstract}

With the increasing use of mobile devices in the world and in Turkey, it is possible for companies to reach customers everywhere at any time. For this purpose, mobile applications are prepared by the companies and offered to the consumers. One of the features that has increasing usage in mobile applications is gamification. Gamification is emerging as a new business strategy with innovative applications to increase sales and customer loyalty. The use of gamification and gamebased applications helps to ensure a positive experience for consumers. Gamification is providing pleasing experience and increase consumers' loyalty. That's why it is important to examine the effects of gamification on consumer buying behavior. The aim of this study is to determine the effects of gamification acceptance in mobile applications on consumer attitudes and intention to use. As a result of this study, it is determined that gamification in mobile applications influences consumers' attitudes and their intention to use.

\section{Keywords}

Gamification • Mobile applications • Attitude • Intention to use • Gamification acceptance

\footnotetext{
* Bu çalışma Bahman HUSEYNLI'nin “Mobil Uygulamalardaki Oyunlaştırma Kabulünün Tüketicilerin Tutumuna ve Kullanım Niyetlerine Olan Etkisinin Belirlenmesi" adlı Yüksek Lisans tezinden türetilmiştir.

2 Sorumlu Yazar: Bahman Huseynli (Dr.), Marmara Üniversitesi, İ̧̧letme Fakültesi, Pazarlama Ana Bilim Dalı, İstanbul, Türkiye. Eposta: bahmanhuseynli92@gmail.com

3 Zehra Bozbay (Doç. Dr.), İstanbul Üniversitesi, İşletme Fakültesi, Pazarlama Ana Bilim Dalı, İstanbul, Türkiye. Eposta: zehrat@istanbul.edu.tr Att: Huseynli, B. ve Bozbay, Z. (2018), Mobil uygulamalarda oyunlaştırma kabulünün tüketicilerin tutumuna ve kullanım niyetlerine olan etkisinin belirlenmesi. Istanbul Business Research, 47(1), 67-90. http://dx.doi.org/10.26650/ibr.2018.47.1.0004
} 
Son yıllarda dünyada ticaretin şeklinin değiştiği görülmektedir. Pazar yerlerinin değişmesi, e-ticaretin payının artışı, internet kullanımının hızla artması, internet kullanımı ve e-ticaretin bilgisayarlardan mobil cihazlara kayması değişimin en önemli etkenlerindendir (TÜSİAD, 2017). Bu doğrultuda markalarla tüketiciler arasındaki etkileşimin de değisstiği görülmektedir. İnternet aracılığıyla hizmet sunan, internet sitelerinin tasarımlar1na yatırım yapan markalar artık mobil uyumlu internet siteleri yaratarak, hatta mobil uygulamalar sunarak tüketicilere daha yakın hale gelmiştir. Mobil uygulamaların e-ticaretteki pay1 2012 yılında \%10 iken, 2016 yılında \%44 olmuştur (TÜSİAD, 2017).

Markalar tüketicilere yönelik yeni yat1rımlar yapmakta ve bu yatırımlar daha çok tüketicilerin eğlenceli ve keyifli deneyim yaşamaları üzerine yoğunlaşmaktadır. $\mathrm{Bu}$ bağlamda tüketicilerin daha çok eğlenmelerine, keyifli zaman geçirmelerine ve daha çok satın almalarına yönelik uygulamalardan biri de oyunlaştırma uygulamalarıdır. Oyunlaştırma ile ilgili uygulamalar 2010 yılından sonra yoğunlaşmış olup gelişmeye devam etmektedir.

Oyunlaştırma uygulamaları markaların başarıya ulaşmasına yardım etmektedir. Uygulamada farklı sektörlerdeki markalar tarafından sunulan oyunaştırma örnekleri olmasına rağmen, literatürde oyunlaştırmanın başarıyla uygulanabileceği ile ilgili çalışmaların eksik olduğu görülmektedir (Hamari, 2013; Huotari ve Hamari, 2012). Ayrıca, oyunlaştırmanın faydaları ile ilgili çalışmalar henüz tamamlanmamıştır (Blohm ve Leimeister, 2013). Filsecker ve
Hickey'e göre (2014) oyunlaştırma araştırmaları henüz emekleme aşamasındadır. Bununla birlikte, oyunlaştırma uygulamada ve teoride gelişmeye devam etmektedir. Konzack'ın (2007) belirttiği gibi oyunlarla ilgili araştırmalar oyun endüstrisine, onun gelişimine ve oyuncuların kabulüne verilen akademik bir yanıttır.

Oyunlaştırma ile ilgili çalışmaların sayıları az olduğundan dolayı konuyla ilgili bütünleşik bir kuram bulunmamaktadır (Hamari, Koivisto ve Sarsa, 2014). Oyunlaştırma hem tüketicilere hem de markalara bazı avantajlar sunmaktadır. Bu doğrultuda oyunlaştırma ile ilgili uygulamalar tüketicilerin hayatına gittikçe daha çok dahil olmaktadır. Bu kapsamda mobil uygulamalardaki oyunlaştırma kabulünün tüketicilerin tutumuna ve kullanım niyetlerine etkisinin incelenmesi çalışmanın amacını oluşturmaktadır.

Mobil uygulamalardaki oyunlaştırmanın tüketicilerin tutumuna ve kullanım niyetleri üzerindeki etkisinin araştırılmasına yönelik literatürde çalışmalar olsa da Türkiye'de bu konu ile ilgili çalışmaların fazla olmadığı görülmüştür. Bu doğrultuda, bu çalışmanın oyunlaştırma literatürüne katkı sağlayacağı düşünülmektedir.

\section{Teorik Altyapı}

\section{Oyunlaştırma ve Oyunlaştırma Unsurları}

Oyunlaştırma müşteri bağlılığını ve satışları artırmak için yenilikçi yollarla yeni bir iş stratejisi olarak ortaya çıkmaktadır. Çevirimiçi olarak tasarlanan oyunlaştırma 
uygulamaları günümüzde müşteri-marka ilişkisinde etkileyici role sahiptir. Çünkü çevirimiçi oyunlar günlük hayatta önemli bir yer tutmaktadır (McGonigal, 2011). Son yıllarda ortaya çıkan oyunlaştırma, akademisyenlerin, eğitimcilerin ve uygulamac1ların dikkatini çekmiştir. Literatür incelendiğinde, oyunlaştırma ile ilgili birçok tanım olduğu görülmektedir. $\mathrm{Bu}$ tanımlardan en çok kabul görenleri Bunchball (2010), Welbach (2014) ve Deterding, Dixon, Khaled ve Nacke'nin (2011a) yaptığı tanımlardır.

Bunchball'a (2010) göre, oyunlaştırma, müşterilerin katılımını sağlamak ve onlarla bağ oluşturmak için oyun özelliklerinin işletmelerin internet sitelerine entegre etme işlemidir. Welbach (2014) oyunlaştırmayı, "müşterilerin katılımını sağlamak ve onlarla bağ oluşturmak için oyun özelliklerinin işletmelerin internet sitelerine entegre etme işlemi ve iş faliyetlerini daha oyunsal hale getirme süreci" olarak tanımlamaktadır.

Deterding v.d ise (2011a, 2011b), endüstri uygulayıcılarının ve akademisyenlerin çalışmalarına dayanan bir oyulaştırma tanımı yapmıştır. Deterding'in (2011a) tanımına göre "oyunlaştırma - oyun özelliklerinin oyun dışı bağlamlarda kullanılması"dır. Bu tanıma kadar farklı araştırmacılar oyunlaştırma ile ilgili farklı tanımlar ortaya koysalar da geniş şekilde kabul görmemiştir. Deterding v.d. (2011a), oyunlaştırmanın "oyunsallık, oyunsal etkileşim ve oyunsal tasarım" unsurlarını belirli bir niyet düşünülerek uygulanmasını içerdiğini önermektedirler. Burada, oyunsallık yaşanılmış deneyimi; oyunsal etkileşim oyuncul deneyimden ortaya çıkan nesneler, cihazlar ve bağlamları; oyunsal tasarım ise oyuna ilişkin tecrübeye dayalı bir deneyim kazanmayı ifade etmektedir.

Werbach ve Hunter (2012) oyunlaştırmayı iş stratejisi olarak kabul ederek ürün, hizmet ve sistem tasarımı sürecinde kullanıldığını söylemektedir. Werbach ve Hunter (2012) oyunlaştırmayı "oyun unsurlar1nın ve oyun tasarım tekniklerinin oyun dışı bağlamlarda kullanılması" olarak tanımlamışlardır. Bu tanım Deterding ve arkadaşlarının (2011a) "oyun unsurları, oyunu oluşturan parçalardır (dinamik, mekanik, bileşen)" şeklindeki tanımına benzemektedir. Werbach ve Hunter (2012) oyunlaşt1rılmış sistemlerin insan psikolojisinden yararlandığını ileri sürmektedirler. Werbach ve Hunter (2012) oyun oynamanın ödüllendirici olması bakımından oyunlaştırmay1 geleneksel motivasyon yapılarına göre daha etkili bir alternatif olarak görmektedirler. Deterding v.d. (2011a) oyunlaştırmanın teknoloji yoluyla uygulandığını vurgulamışlardır. Şöyle ki, Domínguez v.d. (2013) oyunlaştırmayı "kullanıcı deneyimini ve katılımını artırmak için oyun öğelerini oyun dışı bir yazılım uygulamasına dahil etme" şeklinde tanımlamışlardır.

Oyunlaştırmanın ne olup ne olmadığının anlaşılması için güncel bir tanıma ihtiyaç olduğunu belirten Gartner Inc. (2014) oyunlaştırmayı "insanların amaçlarını gerçekleştirmek için dijital olarak etkileşime girmesi ve onları motive etmek için oyun mekaniği ve deneyim tasarımının kullanılması" olarak açıklamıştır (Burke, 2014). Firma ve müşteriler açısından ele alındığında, oyunlaştırmanın hem yöneticilere hem de müşterilere bazı avantajlar sağladığı görülmektedir. Yönetim perspek- 
tifinden, oyunlaştırma müşterilerin dikkatini çekerek, onlarla bağ kurarak ve onları elde tutarak işletmeye katkıda bulunmaktadır. Müşteriler perspektifinden ise, oyunlaştırma doğal olarak eğlenceli, eğitici, kullanımı kolay ve ödüllendiricidir (Yoon, 2009). Genel olarak ele alındığında, oyunlaştırma, müşteri sadakatini (Yoon, 2009) ve ticari hedefleri arttırmakta ve daha iyi müşteri deneyimini sunmaktadır (Choi ve Kim, 2004).

Oyunlaştırma, tam bir oyun tasarlamak yerine oyun dışı amaçla uygulamak için anahtar oyun mekaniğini taklit ederek oyunların etkileşim güçlerini yeniden üretmeye çalışan bir tasarım stratejisidir (Filsecker ve Hickey, 2014). Örgütler oyunlaştırmayı öğrenme ve gelişimi artırmak ve iş hedeflerine ulaşmak için etkili bir araç olarak görmektedirler (Deterding v.d., 2011). Oyunlaştırma tasarımı, kişisel ve hedonistik amaçlı olarak nitelendirilebilirken, oyunlaştırmanın nihai hedefleri genellikle faydacı amaçlarla ilgilidir. Çevrimiçi oyunlarda tasarlanan özelliklerden bazılarını kullanan oyunlaştırma, pek çok başka işletme faaliyetini oyun haline getirebilmektedir. Bu tasarım, işletme hedeflerini tanımlamakla birlikte uygulamaların tanımlanması, uygulanması ve kabulünü içermektedir.

Oyunlaştırmanın müşteriyi elde tutma ve müşteri sadakati üzerinde etkili olabilmesinden önce, müşterilerin ilk olarak oyuncul deneyimlerle meşgul olmaları gerekmektedir (Huotari ve Hamari, 2012). Bunun için de oyunlaştırma faydacı yazılımları daha hedonik olarak yönlendirilmiş yazılıma dönüştürme girişimindedir. Oyunlaştırmanın unsurları oyunlaştırma mekanikleri ve oyunlaştırma dinamikle- ridir. Oyunlaştırma mekaniği, eğlenceli oyun üretmek için tasarlanmış kurallar ve geribildirim döngülerinden oluşmaktadır. Oyunlaştırma dinamikleri ise, oyuncunun girdileri üzerinde hareket eden mekaniğin çalışma zamanındaki davranışlarına uygun belirli mekaniğin uygulanmasıyla beklenen etkileşimlere tepki olarak üretilen oyun desenleridir. Cunnigham ve Zichermann (2011) oyun unsurlarının ve mekaniğinin örneklerle gösterilmiş listesini hazırlamışlardır. Tasarımda dikkat edilmesi gereken hususlar arasinda, bir sistemin hangi oyuncular tarafından destekleneceği, üstatlığın nasıl elde edilebileceği, kurulum yöntemleri (yeni katılımcıların sisteme yönlendirilmesi süreci) ve sosyal katılım döngüsünün rolü sayılabilmektedir. Bunun yanı sira, Bogost (2011) ve Robertson (2010) gibi oyun tasarımc1ları Cunningham ve Zichermann'ın (2011) önermiş olduğu bu unsurların oyunsal bir deneyim sağlamada katkıda bulunup bulunmadığını incelemişlerdir.

Rodrigues, Costa ve Oliveira'nın (2016) çalışmalarında oyunlaştırmanın unsurları ve özelliklerini oluşturmuşlardır. Oyunlaştırma unsurları ve oyunlaştırma özellikleri oyunlaştırma alanında önemli yere sahiptir. Oyun, ürün, güvenlik, süreç ve bilgi oyunlaştırma unsurlarıdır. Oyunlaştırmanın özellikleri ise tasarım, görünüm, işlevsellik, kuramlar (mekanikler) ve amaçlardır (hedefler). Oyunlaştırma unsurları oyunlaştırma özellikleri ile ağlarda ve mobil uygulamalarda kendilerini göstermektedir. Şöyle ki, oyunlaştırma unsuru olan olan "oyun" ağlarda ve mobil uygulamalarda 
"tasarım" olarak kendini göstermektedir. Dolayısıyla, oyunlaştırma unsurları olan "ürün", "güvenlik", "süreç" ve "bilgi" s1rasıyla oyunlaştırma özellikleri olan "görünüm", "işlevsellik", "kurallar (mekanikler)" ve "amaçlar (hedefler)"a uygun gelmektedir (Tablo 1).

Tablo 1

Oyunlaştırma boyutlarının özellikleri ve unsurlarl

\begin{tabular}{ll}
\hline $\begin{array}{l}\text { Oyunlaştırma } \\
\text { Unsurları }\end{array}$ & $\begin{array}{l}\text { Oyunlaştırma } \\
\text { Özellikleri }\end{array}$ \\
\hline Oyun & Tasarım \\
Ürün & Görünüm \\
Güvenlik & İşlevsellik \\
Süreç & Kurallar (mekanikler) \\
Bilgi & Amaçlar (hedefler) \\
\hline
\end{tabular}

Kaynak: Rodrigues, Costa ve Oliveira (2016)

Oyun mekaniği, davranışları güçlü bir şekilde motive etmiş ve etkileyici deneyimler yaratmasının yanı sıra ödül ve tanıma atanması amacıyla oyunları çevreleyen ortamların dişına da uygulanabilir (Rodrigues, Oliveira ve Costa, 2016:115). Oyun mekaniği, bir faaliyeti "oyunsal" yapmak için kullanılan mekanizmalardır (Bunchball, 2010). Oyun mekaniği oyuncunun belirlediği duyguları uyandırmak amacıyla oyunun kuralları ve ödülleri olduğu için oyun dinamikleridir. Oyun dinamikleri ise, bu duygulara yol açan arzular ve motivasyonlardır (Tablo 2).

Tablo 2

Oyun mekaniği ve oyun dinamikleri

\begin{tabular}{ll}
\hline \multicolumn{2}{c}{ Oyun Unsurları } \\
\hline Oyun Mekanikleri & Oyun Dinamikleri \\
\hline Puanlar & Ödül \\
Düzeyler & Durum \\
Zorluklar & Başarı \\
Sanal Ürünler & Kendini İfade Etme \\
Lider Panoları & Rekabet \\
Sanal Hediyeler & Fedakarlık (Altrüizm) \\
\hline
\end{tabular}

Kaynak: Bunchball (2010)
Oyun unsurları birbiriyle bağlantılı olup benzerlik gösterebilmektedirler. Örneğin, "düzey" ve "düzeyleme" gibi terimler geleneksel oyunlar ile oyunlaştırmada farklılık gösterebilmektedir (Seaborn ve Fels, 2015). $\mathrm{Bu}$ farklılıklar uygulamalar, kişiler ve çevre ile birlikte kendini göstermektedir (Tablo 3).

\section{Tüketicilerin Oyunlaştırmayı \\ Kabulü}

Teknoloji Kabul Modeli (Davis, 1989), Gerekçeli Eylem Teorisinden (Theory of Reasoned Action - TRA) (Fishbein ve Ajzen, 1975) uyarlanarak tutum ve davranışların ölçülmesinde kullanılmaktadır. Bu modelin ilk versiyonu yararlılık, kullanım kolaylığı ve davranış niyeti değişkenlerinden oluşmaktadır.

Teknolojiyi Kabul Modeline (TKM) ek değişkenler eklenerek çevrimiçi tüketicilerin

Tablo 3

Oyun unsuru terminolojisi ile ilgili açıklamalar

\begin{tabular}{|c|c|c|}
\hline Terim & Tanımı & Alternatifleri \\
\hline Puanlar & $\begin{array}{l}\text { İlerlemeyi gösteren } \\
\text { sayısal birimler }\end{array}$ & $\begin{array}{l}\text { Deneyim nok- } \\
\text { taları, Skor }\end{array}$ \\
\hline Rozetler & $\begin{array}{l}\text { Başarıları gösteren } \\
\text { görsel simgeler }\end{array}$ & Kupalar \\
\hline $\begin{array}{l}\text { Liderlik Pa- } \\
\text { noları }\end{array}$ & $\begin{array}{l}\text { Karşılaştırma için } \\
\text { sıra görüntüleme }\end{array}$ & $\begin{array}{l}\text { Siralama, } \\
\text { puan tahtası }\end{array}$ \\
\hline İlerleme & $\begin{array}{l}\text { Gelişmeyi gösteren } \\
\text { kilometre taşları }\end{array}$ & $\begin{array}{l}\text { Düzeyleme, } \\
\text { Seviyeyi } \\
\text { düzeltme }\end{array}$ \\
\hline Durum & $\begin{array}{l}\text { İlerlemeyi gösteren } \\
\text { metinsel adlar }\end{array}$ & Başlık, Rütbe \\
\hline Düzeyler & $\begin{array}{l}\text { Giderek zor olan } \\
\text { ortamlar }\end{array}$ & $\begin{array}{l}\text { Sahne alanı, } \\
\text { bölge, dünya }\end{array}$ \\
\hline Ödüller & $\begin{array}{l}\text { Elle tutulur, arzula- } \\
\text { nan eşyalar }\end{array}$ & $\begin{array}{l}\text { Teşvikler, } \\
\text { ödüller, hediye }\end{array}$ \\
\hline Roller & $\begin{array}{l}\text { Rol oynayan karak- } \\
\text { ter elemanları }\end{array}$ & Sinıf, Karakter \\
\hline
\end{tabular}

Kaynak: Seaborn, K. ve Fels, D. I. (2015) 
benimsemesini tahmin etmek için genişletilmiş bir Teknoloji Kabul Modeli elde edilmiştir (Rodrigues, Oliveira ve Costa, 2016). Yeni değişken grubu arasında bilgisayar eğlencesi (Moon ve Kim, 2001), bilişsel emilme (Agarwal ve Karahanna, 2000) ürün ilgilenimi ve algilanan keyif (Koufaris, 2002) yer almaktadır. Eğlenmeye yönelik oyunlaştırma, müşterinin kendi kendini gerçekleştirmesini sağlamayı ve uzun süreli sistem kullanımını teşvik etmeyi amaçlamaktadır (van der Heijden, 2004).

Oyunlaştırmayı benimsemek, iş yazılımları geliştirme gibi alanlardaki hızlı yayılımda görüldüğü gibi müşteri katılımını ve sadakatini artırmak için kullanılan bir pazarlama ve işletme stratejisi olarak da görülmektedir (Dubois ve Tamburrelli, 2013). Davis (1989) tarafindan önerilen TKM'ye bir dizi diş değişken eklenmiştir. Eklenen dış değişkenler arasında sistem kalitesi (Igbaria, Iivari ve Maragahh, 1995), eğitim (Igbaria, Guimaraes ve Davis, 1995), uyumluluk, özyeterlilik, keyif, bilgi işlem desteği ve deneyim (Chau, 1996) değişkenleri vardır. Literatür incelendiği zaman, bu dört değişkenin hem bağımlı hem de bağımsız değişken olarak kullanıldığı görülmüştür. Literatürde tüketicilerin oyunlaştırmayı kabulü ile ilgili Teknoloji Kabul Modelinin yararlılık, kullanım kolaylığı, keyif, eğlenebilirlik ve sosyallik boyutları ile açıklandığı görülmektedir.

Yararlılık, tüketicilerin teknoloji kullanarak belirli bir görevi tamamlama biçimini geliştirmesi ile ilgilidir. Algılanan yararlılık, teknolojiyle olan etkileşimlerin tüketici deneyimine ilişkin algılamalarını ifade etmesidir (Davis, 1989). Yani, algilanan yarar- l1l1l1k, bir kişinin belirli bir bilgi sistemini kullanarak görev performansını artıracağına inanmasina neden olan derecedir. Kullanıcının bir teknolojiyi kullanma niyeti ilk olarak, yararlılık ve kullanım kolaylığından etkilenmektedir (Smith, 2004). İkinci olarak ise kullanım kolaylığı ve kullanma zevkiyle belirlenmektedir (Childers v.d., 2002). Deci ve Ryan'a (2000) göre, yararlılık teknoloji ile ilgili algı ve davranışları ile birlikte kullanım niyetleri üzerinde belirleyici bir faktördür. Ramayah ve Ignatius (2005) internetten alışveriş zamanı teknolojilerin kullanıcı dostu olmamasının yararlılık açısından önemli bir eksiklik olduğunu göstermektedir. Gerrard, Cunningham ve Devlin (2006) ise, algılanan yararlılığın sunulan çevrimiçi hizmetlere ve ürün karışıklığına bağlı olduğunu belirtmektedir.

Bir kişinin fiziksel ve zihinsel çabaya ihtiyaç kalmadan belirli bir bilgi sistemini kullanma derecesi algılanan kullanım kolaylığıdır (Davis, 1989). Kullanımı kolay ve anlaş1ır görünen yazılım, kullanıcının bakış açısına göre daha yararlı olabilmektedir (Ramayah ve Lo, 2007). Yani, kullanılan sistemin başarısı, sistemin kullanım kolaylığına bağlıdır. Teknoloji kabul teorileri üzerine, algılanan kullanım kolaylı̆̆ ni ve zevkini arttırmaktadır (Davis, Bagozzi ve Warshaw, 1989). Algılanan kullanım kolaylığının öneminin ele alınan görevin türüne göre değiştiği de önerilmektedir (Gefen ve Straub, 1997). Aynı zamanda, diğer yönler eşit olduğunda, bir sistemin kullanım kolayl1$\breve{g} 1$ onu daha kullanılabilir olarak algilanmasını sağlamaktır (Venkatesh, 1999). Oyunlaştırma kolay algılanırsa, sistemin engellenmeden 
kullanılması deneyimler kadar etkindir. Bu da hizmeti kullanmaya devam etmek için daha olumlu bir tutum ve daha fazla istek yaratabilmektedir. Özellikle, teknolojinin benimsenmesi için temel öncüllerden biri olarak teknoloji kabulü ile ilgili literatürde kullanım kolaylığı ile ilgili kapsamlı araştırmalar yapılmıştır. Genel olarak, teknoloji daha kolay algılanırsa, daha yararlı (örneğin, Davis v.d., 1989; Venkatesh ve Morris, 2000) ve daha iyi (van der Heijden, 2004) kabul edilmektedir.

Oyun oynamakta birincil hissedilen duygu zevktir (Boyle, Connolly ve Hainey, 2011). Teknoloji kullanımı diğer değişkenlerden etkilendiği gibi keyif algısından da etkilenmektedir. Algılanan keyif, bir kişinin bilgisayar kullanmasının eğlenceli olduğuna inanma derecesini tanımlar (Davis, Bagozzi ve Warshaw, 1989). Literatürde keyif ile ilgili birkaç tane tanım vardır. Davis, Bagozzi ve Warshaw'a (1992) göre, keyif, performansin sonuçlarını dikkate almadan kullanılan bir teknolojidir. Venkatesh (2000) ise, keyifi "bir etkinliğin performans sonuçlarının yanı sıra, gerçekte zevk ve sevinç sağlama olarak algilanma derecesi" olarak tanımlamaktadır. İşletmeler iş verimliliğini artırmak için yeni teknolojileri benimsekte ancak belirli bir görevi yerine getirirken keyif artırmak için bazı teknolojiler de uygulamaktadırlar (Song ve Han, 2009). Oyunlaştırma içeriğine sahip bir işletme yazılımı ortamında, algılanan kullanım kolaylığının keyif üzerinde olumlu bir etkiye sahip olduğunu ve sosyal ipuçları ile finansal okuryazarlık bilgisini geliştirerek, müşterilerin kurum sistemlerini daha fazla kullanmalarını sağladığı görülmüştür (Rodrigues, Oliveira ve Costa, 2016). Algılanan keyfin tüketicilerin teknolojiyi kabulünde önemli bir etkiye sahip olduğu görülmektedir (Van der Heijden, 2004). Bu etkilerin özellikle yazılımlarda büyük etkileri olduğu da kabul edilmektedir.

Eğlenceli etkileşimler, öğrenme sürecine fayda sağlayan ve daha iyi öğrenme sonuçlarına yol açan yaratıcı ve keşfedici davranışları teşvik etmektedir (Perry ve Ballou, 1997). Üstün keyfin yanı sıra, oyunlaştırmanın sistemlerin daha eğlenceli kullanılmasını amaçladığı da iddia edilmektedir. Faaliyeti şekillendiren toplumsal içeriğe dayalı işaretler, onun nasıl algılandığını etkileyebilmektedir (Perry ve Ballou, 1997; Webster ve Martocchio, 1992). Bilgisayar kullanımı bağlamında, eğlenebilirlik kavramı, sistemle olan etkileşimlerde bilişsel içtenlik olarak tanımlanmıştır (Martocchio ve Webster, 1992). Başka bir deyişle, eğlenebilirlik, sistemle etkileşime girerken keşfedici ve yaratıcı davranışları ifade etmektedir (Hamari ve Koivisto, 2015). Bir etkinliğin "iş" veya "oyun" olarak kabul edilmesi, etkinliğe yönelik tutum üzerinde de etki yaratabilmektedir. Şöyle ki, bir etkinlik oyunlaştırıldığında, oyunlaştırma, potansiyel olarak, etkinliğe yaklaşmanın yeni ve yaratıc1 bir yolunu önermektedir. Dolayısıyla, bir oyunlaştırma sistemi ile olan etkileşim, eğlenebilirlik deneyimleri yaratabilmektedir (Lieberman, 1977; Venkatesh, 1999; Webster ve Martocchio, 1992).

Sosyallik, bir internet sitesinde sosyal ipuçlarının kullanımından kaynaklanmaktadır. Wang, Baker, Wagner ve Wakefield (2007) çalışmalarında, tüketicilerin perakendecilerin internet sitelerindeki sosyal ipuçlarını kullanmalarının sosyallik al- 
gılarına yol açtığını ve internet sitelerine pozitif tüketici tepkisi sağladığını ortaya koymuşlardır. Sosyal tepki kuramı insanların bilgisayarların insan özelliklerine sahip olmadıklarını bilmelerine rağmen onları sosyal aktörler olarak ele aldıklarını öne sürmektedir (Moon, 2000). Sosyallik, mobil cihazlar ve bilgisayarların sosyal aktörler olarak ele alınması durumunda bu platformlardaki arayüzlerin kullanıcılar tarafından algılanması olarak tanımlanmaktadır. Oyunlaştırma bağlamında avatarlar, duygusal içerik veya iletişim araçları sosyal ipuçları olarak ele alınmaktadır. Sosyallik, kullanıcıların çevrimiçi bir internet sitesini heyecan verici, eğlenceli ve keyifli olarak yaşayabileceğini varsaymaktadır. Teknolojinin kabulü ile ilgili literatürde, sosyal yönler, başkalarının hedef davranışı gerçekleştirmesini bekleyip beklemediği konusundaki bir kişinin algısına atıfta bulunan sosyal etki olarak yaygın işlev görmektedir (Ajzen, 1991; Fishbein ve Ajzen, 1975). Oyunlaştırma uygulamalarında kullanılan oyun özellikleri karşılıklı şekilde oynanan oyunlardaki gibi sanal ortamlarda da bu olanağı tanımaktadır. Bu açıdan yaklaşıldığında, herhangi bir uygulamanın oyunlaştırma kapsamında değerlendirilmesinde sosyallik kavramına değinmeden geçilemez. Oyunlaştırılmış sistemlerin faydacı ve hedonik özelliklerine ek olarak, yaygın şekilde çağdaş sistemleri etkileyen sosyal özelliklerin uygulanması gibi bir yönü de kullanılmaktadır. Eğlence Yazılım Derneği'ne (Entertainment Software Association) (2014) göre, sosyal oyunların son yıllarda önemli ölçüde arttığı ve sosyal olmayan oyunlarla (oyunun kullanıcının oynadığı oyunlar) karşılaştırıldığında daha popüler olduğu görülmektedir. Aynı zamanda, teknolojiyle daha fazla etkileşimin, kullanıcıların teknolojiye toplumsal olarak yanıt verme olasılığını artırdığı ileri sürülmektedir (Nass v.d., 1997).

\section{Tüketicilerin Yenilikçiliği}

Üretim süreci, hizmet ve teknolojide yapılan değişiklikler yenilik olarak tanımlanmaktadır. Her bir bilim alanında farklı bakış açıları ile ele alınan yenilik, pazarlama ve tüketici davranışları açısından yeni fikirlerin, süreçlerin, ürün veya hizmetlerin ortaya konulması, kabulü ve uygulanması olarak ele alınmaktadır (Kanter, 1983). Satın alma ve/veya kullanım açısından bakıldığında, yeniliğin değer taşıması için müşterinin bu yeniliği kendi lehine çevirmesi gerekmektedir. Yeniliklerin benimsenmesinde önemli olan kavramlardan biri de tüketici yenilikçiliğidir. Tüketici yenilikçiliği yenilikçi ürünlerin pazarda yayılımı açısından önemli bir faktördür. Rogers (2003), tüketici yenilikçiliğini, bireylerin ya da diğer benimseyici birim(ler)in yeni fikirleri bir toplumun diğer üyelerine/birimlerine göre erken benimseme derecesi olarak tanımlamaktadır. Steenkamp ve arkadaşları (1999: 55) ise tüketici yenilikçiliğini, geçmiş tercihler ve tüketim kalıplarından ziyade, yeni ve farklı ürün veya markaları satın almaya yönelik eğilim şeklinde tanımlamışlardır. Ayrıca, tüketici yenilikçiliğinin bazı bireylerin yeni ürünleri benimseme eğilimi olarak tanımlandığ 1 da görülmektdir (Cowart, Fox ve Wilson, 2008: 517; Tellis, Yin ve Bell, 2009; Goldsmith, Kim, Flynn ve Kim, 2005). 
Oyunlaştırma, teorik açıdan yeni bir kavram olmakla birlikte müşteri kazanımı, müşteriye keyifli deneyim sunma ve müşteriyi elde tutma ile ilgili uygulamalarda da yeni bir yöntem olarak ortaya çıkmıştır. Tüketicilerin oyunlaştırma içerikli mobil uygulamalarının farkında olmaları yenilikçilik algısı ile ölçülebildiği varsayımından yola çıkarak araştırmanın modeline tüketicilerin yenilikçiği değişkeni dâhil edilmiştir.

\section{Tüketicilerin İlgilenimi}

Pazarlamada ve tüketici araştırmalarında ilgilenimin önemi yıllardır bilinmektedir. $\mathrm{Bu}$ kavram, çeşitli tüketici davranışı ve pazarlama yapılarıyla bağlantılı olup ürünleri ve reklam mesajlarını uyarı seviyesine göre sınıflandırmak için kullanılmıştır. Tüketici ilgilenimi ile ilgili çalışmalar Sherif ve Cantril'in (1947) araştırmasına kadar uzanmaktadır. İlgilenim tüketici davranışları ile ilgili araştırmalarda birçok yazar (Arora, 1982; De Bruicker, 1979; Robertson, 1976) tarafından incelenmiştir. İlgilenimin, literatürde kişisel ilgilere odaklanan altta yatan bir motif olarak ele alındığı görülmektedir (Greenwald ve Leavitt, 1984; Krugman, 1965; Mitchell, 1979). Reklamcilıkta ilgilenim, reklamın alıcının kişisel olarak etkilenmesi açısından "ilgili" hale getirilmesi şeklinde ele alınmaktadır (Petty ve Cacioppo, 1981). Ürün sınıfı araştırmasında ise, ürünün tüketicinin ihtiyaç ve değerlerine "uygunluğu" ve dolayisiyla ürün bilgisine olan ilgisiyle açıklanmaktadır (Zaichkowsky, 1986). Satın alma karar araştırmasında ise bu, kararın "alakalı" olması ve dolayısıyla tüketicinin dikkatli bir satın alma kararını vermesi için motive etmesidir. Teorik olarak ele alındığında, ilgilenim bireysel fark değişkenidir. Tüketici satın alma davranışında birtakım sonuçlarla birlikte nedensel veya motive edici bir değişken olarak ele alınmaktadır. Dolayısıyla, tüketiciler ilgilenim düzeylerine bağlı olarak, satın alma karar süreçlerinin kapsamı açısından büyük farklilıklar göstermektedir.

Araştırma mobil uygulamalardaki oyunlaştırmanın tüketicilerin kullanım niyeti ve tutumları üzerindeki etkisini ölçmek için tasarlanmıştır. Tüm araştırmalarda olduğu gibi bu araştırmada da doğru örneklem üzerinde uygulama yapılmasına önem verilmiştir. $\mathrm{Bu}-$ nunla birlikte, herhangi bir mobil uygulamada var olan oyunlaştırma unsurlarının farkında olmak ve onu kullanmak için tüketicinin ilgi düzeyi önem arz etmektedir. Buradan hareketle, araştırma modelinde tüketicilerin ilgilenimi değiş̧eni de dâhil edilmiştir.

\section{Tüketicilerin Tutumları}

Tutum teriminin farklı tanımları bulunmaktadır. Howarth'e (2006) göre tutum herhangi bir şeyi olumlu veya olumsuz yönüyle açıklayan ve değerlendiren psikolojik bir eğilim olarak açıklanmaktadır. Tutumlar insan davranışlarında önemli bir yere sahip olup öğrenme sonucunda oluşmaktadırlar. Tutumlar farklı kaynaklardan gelen etkenler sonucunda oluşmaktadırlar. Ayrıca, tutumlar sonradan öğrenilen davranışlar olup, tutumların değiştirilmesi de mümkündür. Fakat tutumların değiştirilmesi kolay değildir. Tutumlar bireylere dört farklı fonksiyonu ile etki etmektedir (Okumuş, 2013): faydacı/yararlı olma işlevi; değer ifade etme işlevi; ego/ benlik koruma/savunma işlevi; bilgi işlevidir. 
Bireylerin tutumlarının açıklanmasında tutumun bileşenlerinden yararlanılmaktadır. Tutumun bilişsel, duygusal ve davranışsal olmak üzere üç bileşeni vardır. Tüketicilerin bir nesne hakkındaki inançları, düşünceleri ve bilgilerinden oluşan tutumları bilişsel bileşen olarak açıklanmaktadır. Tüketicilerin duygu ve hislerinden meydana gelen bileşen ise duygusal bileşendir. Daha önce oluşmuş olumlu ya da olumsuz duygular sonucunda belirli bir şekilde davranma eğilimi ise davranışsal bileşeni oluşturmaktadır (Assael, 1984; Okumuş, 2013). "Bir nesne, kişi, kurum ya da olaya olumlu ya da olumsuz cevap verme eğilimi”, olarak tanımlanan tutum (Ajzen, 2005) davranışsal niyetin en önemli belirleyiciden biridir. Literatürdeki çalışmaların çoğunda tutumu belirlemek için tutumdan davranışa doğru fiili bir nedensel bağlantı vardır (Huang, Lee ve Hsun Ho, 2004). Bununla beraber, literatürde tutum ve davranışsal niyeti birlikte araştıran çalışmalar da bulunmaktadır. Genel olarak tutumlar, belirli sonuçların belirli davranışlarla ilişkili olduğu inancina dayanarak oluşturulmuştur. $\mathrm{Bu}$ inançlar ve sonuçlar olumlu veya olumsuz olarak değerlendirilmektedir (Ajzen, 1991). Bunun yanı sıra davranışlara yönelik tutumların sosyal etkiyle birlikte davranışsal niyetlerin güvenilir öngörücüleri olduğu da gösterilmiştir (Ajzen, 1991; Fishbein ve Ajzen, 1975).

Literatürde, yeniliğin kabulü ile tüketici tutumları (Ellis ve Webster, 1999; Park, Davis Burns ve Rabolt, 2007; Boisvert ve Ashill, 2011; Sanayei, Shahin ve Taherfar, 2013) ve tüketici tutumları ile satınalma niyetleri (Till ve Busler, 2000; Spears ve Singh, 2004; Seock ve Norton, 2007; Zhang ve Kim, 2013; He, Chen ve Alden,
2016) arasındaki ilişkileri inceleyen çalışmalar yer almaktadır. $\mathrm{Bu}$ doğrultuda bu çalışmada mobil uygulamalarda oyunlaştırmanın kabulünün mobil uygulamalara ilişkin tüketici tutumları üzerindeki etkilerini ve mobil uygulamalara ilişkin tüketici tutumlarının mobil uygulamalara ilişkin kullanım niyetlerine olan etkilerini belirlemek amacıyla tüketici tutumları değişkeni araştırmanın modeline dâhil edilmiştir.

\section{Tüketicilerin Kullanım Niyeti}

Niyet, davranışların iyi bir belirteçi olarak kabul edilmektedir. "Davranışsal niyet" kavramı, bireyin belli bir davranış motivasyonunun davranışı etkileyen tutumlarla tanımlandığını iddia etmektedir (Fishbein ve Ajzen, 1975). Davranış niyeti bir internet kullanıcısının çevrimiçi alışveriş için olumlu (beğenilen) veya olumsuz (beğenilmeyen) yanıtı olan bilişsel seçimine bağlıdır. Davis'e (1989) göre, davranış niyeti, bir kişinin bir ürünü veya hizmeti satın alması veya kabul etmesi olasılığını ölçer. Teknoloji Kabul Modeli'ne göre, kullanım niyetinin belirlenmesinde iki önemli belirleyici vardır. Bunlar, algilanan yararlılık ve algılanan kullanım kolaylığıdır. Tüketicilerin teknolojiyi kullanma niyetini etkileyen birçok faktör vardır. Bunlardan biri de algılanan keyiftir. Hedonik bilgi sistemleri üzerine yapılan bir çalışmada, zevkten yoksunluğun kullanma niyetini etkilediği görünmektedir (Van der Heijden, 2004). Yani, bir sistemi kullanmak kolay olursa, keyif artar, ne kadar zor olursa keyif azalır. Sistemi kullanmanın kolay algılanması ve keyifle ilişkilendirilmesi ise kullanmaya yönelik tutumların yaratılmasına yol açmaktadır. Kullanım niyeti ile ilgili farklı 
alanlarda yapılmış çalışmalar vardır. Oyunlaştırma alanı ile ilgili yapılan çalışmalarda (Atkinson ve Kydd, 1997; Hamari, 2015b; Mäntymäki ve Riemer, 2014; Moon ve Kim, 2001; van der Heijden, 2004; Venkatesh, 1999) oyunlar, oyun benzeri sistemler ve eğlence amaciyla kullanılan diğer sistemler bağlamında, sistemin kullanılmasından algilanan keyif kullanım niyetlerini etkileyen önemli bir faktör olarak gösterilmiş̧ir.

Oyunlaştırmanın amacı, sistemleri tam teşekküllü oyunlara dönüştürmek değil, daha çok motive edici ve çekici hale getirmek veya kullanıcıların davranışlarını anlamlı bir şekilde değiştirmek için bazı oyun öğelerinin uygulanmasıdır. Oyunlaştırma bağlamında, oyunlaştırılmış hizmete yönelik bir tutum, benzer şekilde onu kullanma niyetini etkilediği düşünüldüğü gerekçesiyle araştırmanın modeline dâhil edilmiştir.

\section{Araştırmanın Metodolojisi}

\section{Araştırmanın Amacı, Kapsamı ve Kisitları}

Tüketicilere keyifli deneyim sunan ve onların markaya bağlılığını artırmayı hedefleyen (Yoon, 2009; Childers v.d., 2001; Holzwarth, Janiszewski ve Neumann, 2006; Teo ve Noyes, 2011) mobil uygulamalardaki oyunlaştırma özelliklerinin tüketicilerin tutum ve kullanım niyetleri ile etkileşimlerini belirlemek önem arz etmektedir. Bu doğrultuda, çalışmanın amacı, mobil uygulamalardaki oyunlaştırma kabulünün tüketicilerin tutumuna ve kullanım niyetlerine olan etkisinin belirlenmesidir.
Günümüzde, markalar tarafından tüketicilerin hizmetlerine sunulan oyunlaştırma özellikli mobil uygulamalar, tüketicilerin ilgilenim düzeyleri, yenilikçilikleri ve mobil uygulamalardaki oyunlaştırma kabulü arasındaki ilişkilerin belirlenmesi de önemlidir. Buradan hareketle, çalışmanın ana amacının yanı sıra alt amaçları da vardır. Mobil uygulamalardaki oyunlaştırma kabulü ile tüketicilerin yenilikçiliği arasında ilişkinin olup olmadığını belirlemek, mobil uygulamalardaki oyunlaştırma kabulü ile tüketicilerin ilgilenim düzeyleri arasında ilişkinin olup olmadığını belirlemek çalışmanın alt amaçları arasında yer almaktadır. Ayrıca, sosyo-demografik özellikleri itibariyle tüketicilerin mobil uygulamalardaki oyunlaştırma kabulüne ilişkin farkl1lık gösterip göstermediğini belirlemek de çalışmanın bir diğer alt amacıdır.

Tüketicilerin "oyunlaştırma” kavramına tam aşina olmamalarından dolayı, araştırma sektör fark etmeksizin oyunlaştırma özellikli tüm mobil uygulamaları kullanan tüketicilere uygulanmıştır. Araştırma oyunlaştırma özellikli tüm mobil uygulamaları kullanan tüketicilere uygulanmıştır. Araştırmada örneklemin seçilmesinde kolayda örnekleme yöntemi kullanılmıştır. Araştırmanın verileri çevrimiçi anket yöntemi kullanarak toplanmıştır. İfadelerin anlaşılırlığını test etmek amacıyla Mayıs 2017'de 20 kişilik katılımcı grubuna ve Haziran 2017'de 35 kişilik kat1lımcı grubuna ön anket uygulanmıştır. İlk ön ankete göre sonraki ön anketteki ifadelerin katılımcılar tarafindan daha iyi anlaşıldığı görülmüştür. Araştırmanın verileri 26 Haziran 2017 - 26 Temmuz 2017 tarihleri ara- 
sinda 435 kişiden internet üzerinden anket yöntemi ile toplanmıştır.

Araştırmada, tüketicilerin yenilikçiliğini ölçmede Hirunyawipada ve Paswan (2006); tüketicilerin ilgilenimini ölçmede Zaichkowsky (1994); mobil uygulamalarda oyunlaştırmanın kabulünü ölçmede Davis (1989); Webster ve Martocchio (1992); van der Heijden (2004); Wakefield, Wakefield, Baker ve Wang (2011); tutumu ölçmede Ajzen (1991) ve kullanım niyetini ölçmede Davis, Bagozzi ve Warshaw (1989) çalışmalarından yararlanılmıştır. Araştırmada, tüketicilerin yenilikçiliği toplam dört, tüketicilerin ilgilenimi toplam alt1, mobil uygulamalarda oyunlaştırmanın kabulü toplam 30, tüketicilerin tutumu toplam dört ve kullanım niyeti toplam üç değişken ile ölçülmüştür.

\section{Araştırmanın Modeli ve Hipotezleri}

Araştırmanın amacı doğrultusunda geliştirilen hipotezler aşağıdaki gibidir:

$>\mathbf{H}_{\mathbf{1}}$ : Tüketicilerin yenilikçiliği ile mobil uygulamalardaki oyunlaştırmanın kabulü arasında anlamlı bir ilişki vardır.

$>\mathbf{H}_{2}$ : Tüketicilerin ilgilenimi ile mobil uygulamalardaki oyunlaştırmanın kabulü arasında anlamlı bir ilişki vardır.

$>\mathbf{H}_{3}$ : Mobil uygulamalardaki oyunlaştırmanın kabulü tüketicilerin sosyodemografik özelliklerine göre farklılık göstermektedir.
$>\mathbf{H}_{4}$ : Mobil uygulamalardaki oyunlaştırmanın kabulü tüketicilerin mobil uygulamalardaki oyunlaştırmaya ilişkin tutumlarını etkilemektedir.

$>\mathbf{H}_{\mathbf{5}}$ : Mobil ugulamalardaki oyunlaştırmanın kabulü tüketicilerin mobil uygulamalardaki oyunlaştırmaya ilişkin kullanım niyetlerini etkilemektedir.

$>\mathbf{H}_{\mathbf{6}}$ : Tüketicilerin mobil uygulamalardaki oyunlaştırmaya ilişkin tutumları tüketicilerin mobil uygulamalardaki oyunlaştırmaya ilişkin kullanım niyetlerini etkilemektedir.

Araştırmanın değişkenlerinin yer aldığı araştırma modeli Şekil 1'de verilmiştir.

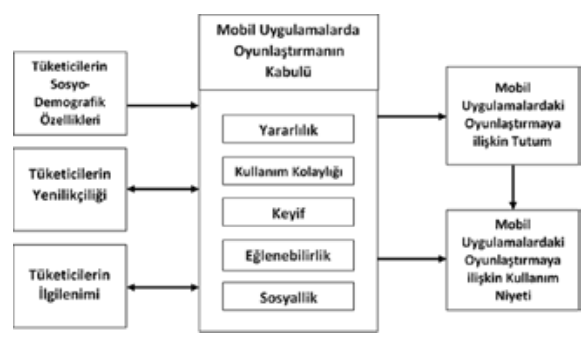

Sekil 1

Araştırmanin Modeli

\section{Araştırmanın Bulguları}

Araştırmaya katılanların \%44,1'ni erkek, \%55,9'nu ise kadın katılımcılar oluşturmaktadır. Katılımcıların \%24,4'ünü evli, \%75,6'sını ise bekar bireyler oluşturmaktadır. Araştırmaya katılanların \%47,1'i 18-25 yaşları arasında, \%38,6's1 26-35 yaşları arasında, \%10,1'i 36-45 yaşları arasında, \%2,5'i 46-55 yaşları arasında, $\% 1,2$ 'si 56-65 yaşları arasında ve \%0,5'i 66 yaşın üstünde yer almaktadır. Ayrıca, araştırmaya katılanların \%0,5'ni ilkokul 
mezunları, \%11,9'nu yüksekokul mezunları, 57,7'sini üniversite mezunları, 22,8'ni yüksek lisans mezunları ve \%2,3'nü doktora mezunları oluşturmaktadır. Katılımcıların \%37,9'nu öğrenciler, \%0,7'sini ev hanımları, \%1,4'nü emekliler, \%24,1'ni özel sektör çalışanları, \%22,8'ni kamu sektörü çalışanları ve $\% 13,1$ 'ni ise diğer sektör çalışanları oluşturmaktadır. Araştırmaya katılanların \%32,9'nu 1000 TL ve aşağı gelir düzeyine, $\% 20$ 'sinin 1001-2000 TL aras1 gelir düzeyine, \%19,1'ni 2001-3000 TL aras1 gelir düzeyine, $\% 13,3$ 'nü 3001-4000 TL aras1 gelir düzeyine, \%7,1'ni 4001$5000 \mathrm{TL}$ arası gelir düzeyine, $\% 7,6$ 'sinı ise $5001 \mathrm{TL}$ ve daha fazla gelir düzeyine sahip bireyler oluşturmaktadır.

Araştırmaya katılanların mobil uygulamalarda hediye puanları kullanım sıklıkları itibariyle dağılımlarına göre katılımcıların $\% 52,4$ 'ü (228 kat1lımc1) ayda 1-2 defa mobil uygulamalarda hediye puan kazanmaktadır. Araştırmaya katılanların \%25,6'sı haftada 1-2 defa, \%15,6's1 ayda 3-4 defa ve $\% 6,4$ 'ü ise her gün mobil uygulamalarda hediye puan kazanmaktadır. Araştırmaya katılanların mobil uygulamalarda hediye puanları kullanım süreleri itibariyle dağılımına göre katılımcıların \%31,9'u (139 katılımc1) 6 aydan az süredir mobil uygulamalarda hediye puan kazanmaktadır. Araştırmaya katılanların \%25,6'sı haftada 6 ay-1 y1l aras1, \%23,7'si 1-3 y11 aras1 ve $\% 19,8$ ' $\mathrm{i}$ ise 3 yıldan fazla süredir mobil uygulamalarda hediye puan kazanmaktadır.
Tablo 4

Araştırmaya katılanların sosyo-demografik özellikleri

\begin{tabular}{|c|c|c|}
\hline Sosyo-Demografik Özellikler & Say1 & Yüzdesi (\%) \\
\hline \multicolumn{3}{|l|}{ Cinsiyet } \\
\hline Erkek & 192 & 44,1 \\
\hline Kadın & 243 & 55,9 \\
\hline \multicolumn{3}{|l|}{ Medeni Durum } \\
\hline Evli & 106 & 24,4 \\
\hline Bekâr & 329 & 75,6 \\
\hline \multicolumn{3}{|l|}{ Yaş } \\
\hline $18-25$ & 205 & 47,1 \\
\hline $26-35$ & 168 & 38,6 \\
\hline $36-45$ & 44 & 10,1 \\
\hline $46-55$ & 11 & 2,5 \\
\hline $56-65$ & 5 & 1,2 \\
\hline 65 ve üzeri & 2 & 0,5 \\
\hline \multicolumn{3}{|l|}{ Eğitim Düzeyi } \\
\hline İlkokul Mezunu & 2 & 0,5 \\
\hline Lise Mezunu & 52 & 1,9 \\
\hline Yüksekokul Mezunu & 21 & 4,8 \\
\hline Üniversite Mezunu & 251 & 57,7 \\
\hline Yüksek Lisans Mezunu & 99 & 22,8 \\
\hline Doktora Mezunu & 10 & 2,3 \\
\hline \multicolumn{3}{|l|}{ Meslek } \\
\hline Öğrenci & 165 & 37,9 \\
\hline Ev Hanımı & 3 & 0,7 \\
\hline Emekli & 6 & 1,4 \\
\hline Özel Sektör & 105 & 24,1 \\
\hline Kamu Sektörü & 99 & 22,8 \\
\hline Diğer & 57 & 13,1 \\
\hline \multicolumn{3}{|c|}{ Aylık Gelir Seviyesi (Türk Lirası ile) } \\
\hline 1000 ve altı & 143 & 32,9 \\
\hline $1001-2000$ & 87 & 20 \\
\hline $2001-3000$ & 83 & 19,1 \\
\hline $3001-4000$ & 58 & 13,3 \\
\hline $4001-5000$ & 31 & 7,1 \\
\hline 5001 ve üzeri & 33 & 7,6 \\
\hline
\end{tabular}

Araştırmada kullanılan ölçeklerin faktör yapılarını ve geçerliliklerini belirlemek amacıyla faktör analizi uygulanmıştır. Ölçeklere ilişkin faktör analizi yürütülmeden önce bu analizin uygun istatistiksel teknik olup olmadığını belirlemek amacıyla KMO örnekleme uygunluk ölçümü ve Bartlett's testi yapılmıştır. Tüm değişkenlerde bu değerler 0,50 'den yüksek olduğundan analize devam edilmiştir. Mobil uygulamalardaki oyunlaştırmanın kabulü 32 değişkenli ölçek ile ölçülmüş fakat iki değişken düşük faktör yükleri nedeniyle analizden çıkarılmıştır. 
Uygulanan keşfedici faktör analizi sonucunda mobil uygulamalardaki oyunlaştırmanın kabulüne dair beş faktör elde edilmiştir. Faktörlerin her biri literatüre uygun olarak kullanım kolaylığı, yararlılık, eğlenebilirlik, keyif ve sosyallik olmak üzere isimlendirilmiştir. Tüketici ilgilenimi on değişkenli ölçek ile ölçülmüş fakat dört değişken düşük faktör yükleri nedeniyle analizden çıkarılmıştır. Uygulanan faktör analizi sonucunda tüketici ilgilenimi ölçeği tek boyuttan oluşmaktadır. Araştırmada yer alan diğer değişkenler olan tutum, kullanım niyeti, tüketici yenilikçiliği ölçeklerine yönelik yapılan faktör analizi sonucunda ise ölçeklerin tüm maddelerinin faktör yükleri yüksek sonuç göstermiş olup ölçeklerin tek boyuttan oluştuğu bulunmuştur.

Araştırmada tüketicilerin yenilikçiliği ölçeği tarafından açıklanan varyans $\% 69,393$, tüketicilerin ilgilenimi ölçeği tarafından açıklanan varyans $\% 75,268$, mobil uygulamalarda oyunlaştırmanın kabulü ölçeği tarafindan açıklanan varyans $\% 72,289$, tutum ölçeği tarafindan açılanan varyans $\% 80,608$ ve kullanım niyeti ölçeği tarafından açıklanan varyans $\% 90,517$ olarak bulunmuştur. Araştırmada kullanılan ölçekler tarafından açıklanan varyans kritik değer olan \%60'1n üzerinde bulunmuştur (Hair, Black, Babin ve Anderson, 2010).

Araştırmada kullanılan ölçeklerin güvenilirliklerini belirlemek için Cronbach's Alpha katsayısı hesaplanmıştır. Tüketicilerin yenilikçiliği ölçeğinin Cronbach's Alpha değeri 0,852 , tüketicilerin ilgilenimi ölçeğinin Cronbach's Alpha değeri 0,933, mobil uygulamalarda oyunlaştırmanın kabulü ölçeğinin Cronbach's Alpha değeri 0,956, tutum ölçeğinin Cronbach's Alpha değeri 0,919 ve kullanım niyeti ölçeğinin Cronbach's Alpha değeri ise 0,948 olarak bulunmuştur. Hesaplanan Cronbach's Alpha değerleri \%70'in üzerinde olup ölçekler güvenilirdir (Hair v.d., 2010).

Tüketicilerin yenilikçiliği ile mobil uygulamalardaki oyunlaştırmanın kabulü arasındaki ilişkiyi belirlemek için $\left(\mathrm{H}_{1}\right.$ hipotezi) korelasyon analizi uygulanmıştır. Tüketicilerin yenilikçiliği ile mobil uygulamalardaki oyunlaştırmanın kabulü arasında anlamlı bir ilişki olduğu tespit edilmiştir. Tüketici yenilikçiliği ile mobil uygulamalardaki oyunlaştırmanın kabulünün kullanım kolaylığ $1(, 342)$, yararlılık (,496), eğlenebilirlik $(, 604)$ ve keyif $(, 586)$ boyutları arasında orta düzeyde pozitif ilişki ve sosyallik $(, 705)$ boyutu arasında ise kuvvetli düzeyde pozitif ilişki olduğu bulunmuştur (Tablo 5).

Tüketicilerin ilgilenimi ile mobil uygulamalardaki oyunlaştırmanın kabulü arasındaki ilişkinin testi için $\left(\mathrm{H}_{2}\right.$ hipotezi) korelasyon analizi uygulanmıştır. Tüketicilerin ilgilenimi ile mobil uygulamalardaki oyunlaştırmanın kabulü arasında anlamlı bir ilişki olduğu görülmüştür. Tüketici ilgilenimi ile mobil uygulamalardaki oyunlaştırmanın kabulünün kullanım kolayl1ğ1 (,422), yararlılık $(, 501)$, eğlenebilirlik $(, 657)$ boyutları arasında orta düzeyde pozitif ilişki; keyif $(, 771)$ ve sosyallik $(, 748)$ boyutları arasında ise yüksek düzeyde pozitif ilişki olduğu saptanmıştır (Tablo 6).

Araştırmada tüketicilerin sosyo-demografik özellikleri itibariyle mobil uygulamalardaki oyunlaştırmanın kabulü üzerinde 
Tablo 5

Tüketicilerin yenilikçiliği ile mobil uygulamalardaki oyunlaştırmanın kabulü arasındaki ilşiki

\begin{tabular}{lcccccc}
\hline & Tüketici Yenilikçiliği & Kullanım Kolaylığı & Yararlılık & Eğlenebilirlik & Keyif & Sosyallik \\
\hline $\begin{array}{l}\text { Tüketici Yeni- } \\
\text { likçiliği }\end{array}$ & 1 & & & & & \\
Kullanım &, $342^{* *}$ & 1 & & & & \\
Kolaylığı &, $496^{* *}$ &, $483^{* *}$ & 1 & & & \\
Yararlılık &, $604^{* *}$ &, $280^{* *}$ &, $504^{* *}$ & 1 & & \\
Ĕglenebilirlik &, $586^{* *}$ &, $362^{* *}$ &, $471^{* *}$ &, $690^{* *}$ & 1 & \\
Keyif &, $705^{* *}$ &, $364^{* *}$ &, $538^{* *}$ &, $733^{* *}$ &, $697^{* *}$ & 1 \\
Sosyallik & & & & & & \\
\hline
\end{tabular}

farklılığın olup olmadığı $\left(\mathrm{H}_{3}\right.$ hipotezi) test edilmiştir. Bu doğrultuda, katılımcıların cinsiyet ve medeni durum değişkenleri itibariyle farklılığın testi için bağımsız değişkenler $t$ testi uygulanmıştır. Tüketicilerin cinsiyetleri itibariyle mobil uygulamalardaki oyunlaştırmanın kabulüne ilişkin algıları arasında kullanım kolaylığı boyutu itibariyle farklılık olduğu saptanmıştır $(\mathrm{p}=0,023)$. Tüketicilerin medeni durumları itibariyle mobil uygulamalardaki oyunlaştırmanın kabulüne ilişkin algıları arasında ise yararlılık boyutu itibariyle farkl11ık olduğu saptanmıştır $(\mathrm{p}=0,003)$.

Yaş aralı̆ğ1, eğitim durumu, meslek ve aylık gelir değişkenleri itibariyle mobil uygulamalardaki oyunlaştırmanın kabulünde farklılı̆̆ın belirlenmesi amacıyla tek yönlü ANOVA analizi yapılmıştır. Analiz sonucuna göre yaş aralığı değişkeni ile mobil uygulamalardaki oyunlaştırmanın kabulü değişkenin alt değişkenleri incelendiğinde; kullanım kolaylı̆̆ı, yararlılık, eğlenebilirlik, keyif ve sosyallik boyutlarının $\mathrm{p}=0,05$ önem derecesinde mobil uygulamalardaki oyunlaştırmanın kabulü değişkenine göre farkl1lık gösterdiği saptanmıştır.

Araştırmaya katılanların aylık gelir düzeyleri itibariyle mobil uygulamalardaki oyunlaştırmanın kabulü değişkeni arasın- daki farklılığı tespit etmeye yönelik yap1lan analiz sonucunda; yalnızca yararlılık boyutunun $p=0,05$ önem derecesinde mobil uygulamalardaki oyunlaştırmanın kabulüne göre farklılık gösterdiği saptanmış, diğer değişkenler itibariyle anlamlı bir farklılık bulunmamıştır. Bu hipotezde anlamlı çıkanlar itibariyle erkek ve kadınların kullanım kolaylığının, evli ve bekar katılımcıların algıladıkları yararlılığın ve gelir düzeyi seviyelerine göre algıladıkları yararlılığın farklılaştığı bulunmuştur. Ayrıca, katılımcıların yaşlarının artması ile kullanım kolaylığı, yararlılık, eğlenebilirlik, keyif ve sosyallik boyutlarının da değiştiği saptanmıştır.

Mobil uygulamalardaki oyunlaştırmanın kabulünün tüketicilerin mobil uygulamalardaki oyunlaştırmaya ilişkin tutumları üzerindeki etkisini test etmek için $\left(\mathrm{H}_{4}\right.$ hipotezi) regresyon analizi uygulanmıştır. Kurulan regresyon modelinin açıklama gücü 0,632 olup, bu da tutum değişkenindeki varyasyonun \%63,2'sini mobil uygulamalardaki oyunlaştırma değişkeninin alt boyutları olan sosyallik, kullanım kolaylığı, keyif ve eğlenebilirlik değişkenleri ile açıklanabildiğini göstermektedir. Tablo 7'de görüldügü üzere, mobil uygulamalardaki oyunlaştırmanın kabulünün alt boyutları incelendiğinde; sosyallik $(\beta=, 560$, $\mathrm{p}<0.005)$, keyif $(\beta=, 411, \mathrm{p}<0.005)$ ve kulla- 
Tablo 6

Tüketicilerin ilgilenimi ile mobil uygulamalardaki oyunlaştırmanın kabulü arasındaki ilișki

\begin{tabular}{|c|c|c|c|c|c|c|}
\hline 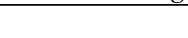 & Tüketici İlgilenimi & Kullanım Kolaylığı & Yararlılık & Eğlenebilirlik & Keyif & Sosyallik \\
\hline $\begin{array}{l}\text { Tüketici İlgile- } \\
\text { nimi }\end{array}$ & 1 & & & & & \\
\hline $\begin{array}{l}\text { Kullanım } \\
\text { Kolaylığı }\end{array}$ &, $422 * *$ & 1 & & & & \\
\hline Yararlılık &, $501 * *$ &, $483 * *$ & 1 & & & \\
\hline Eğlenebilirlik &, $657 * *$ &, $280 * *$ &, $504 * *$ & 1 & & \\
\hline Keyif &, $771 * *$ &, $362 * *$ &, $471 * *$ &, $690 * *$ & 1 & \\
\hline Sosyallik &, $748 * *$ &, $364 * *$ &, $538 * *$ &, $733 * *$ &, $697 * *$ & 1 \\
\hline
\end{tabular}

nım kolaylı̆ğ $(\beta=, 143, p<0.005)$ boyutlarının oyunlaştırmaya ilişkin tutum üzerinde pozitif ve anlamlı bir etkisi olduğu görülmüştür. Mobil uygulamalardaki oyunlaştırmanın kabulünün eğlenebilirlik boyutunun $(\beta=-, 302$, $\mathrm{p}<0.005$ ), ise oyunlaştırmaya ilişkin tutum üzerinde negatif ve anlamlı bir etkisi olduğu görülmüştür (Tablo 7). Araştırmada mobil uygulamalardaki oyunlaştırmanın kabulünün tüketicilerin mobil uygulamalardaki oyunlaştırmaya ilişkin tutumları üzerinde etkili olduğu bulunmuştur $\left(\mathrm{R}^{2}=0,632\right)$.

Mobil uygulamalardaki oyunlaştırmanın kabulünün tüketicilerin mobil uygulamalardaki oyunlaştırmaya ilişkin kullanım niyetleri üzerindeki etkisini belirlemek için $\left(\mathrm{H}_{5}\right.$ hipotezi) regresyon analizi uygulanmıştır. Kurulan regresyon modelinin açıklama gücü 0,541 olup, bu da kullanım niyeti değişkenindeki varyasyonun $\% 54,1$ 'ni mobil uygulamalardaki oyunlaştırma değişkeninin alt boyutları olan sosyallik, kullanım kolaylığ 1 ve keyif değişkenleri ile açıklanabildiğini göstermektedir. Mobil uygulamalardaki oyunlaştırmanın kabulünün alt boyutları incelendiğinde; sosyallik $(\beta=, 408, p<0.005)$, keyif $(\beta=, 361$, $\mathrm{p}<0.005)$ ve kullanım kolaylığ $(\beta=, 101$, $\mathrm{p}<0.005)$ boyutlarının oyunlaştırmaya ilişkin kullanım niyeti üzerinde pozitif ve an- lamlı bir etkisi olduğu görülmüştür (Tablo 8). Mobil uygulamalardaki oyunlaştırmanın kabulünün, mobil uygulamalardaki oyunlaştırmaya ilişkin kullanım niyetleri üzerindeki etkisinin bulunduğu görülmüştür $\left(\mathrm{R}^{2}=0,541\right)$.

Tüketicilerin mobil uygulamalardaki oyunlaştırmaya ilişkin tutumlarının tüketicilerin mobil uygulamalardaki oyunlaştırmaya ilişkin kullanım niyetleri üzerindeki etkisini test etmek için $\left(\mathrm{H}_{6}\right.$ hipotezi) regresyon analizi uygulanmıştır. Kurulan regresyon modelinin açıklama gücü 0,524 olup, bu da kullanım niyeti değişkenindeki varyasyonun \%52,4'ni mobil uygulamalardaki oyunlaştırmaya ilişkin tutum ile açıklanabildiğini göstermektedir. Tüketicilerin mobil uygulamalardaki oyunlaştırmaya ilişkin tutumlarının mobil uygulamalardaki oyunlaştırmaya ilişkin kullanım niyetleri üzerinde $(\beta=, 724, p<0.005)$ etkili olduğu saptanmıştır $\left(\mathrm{R}^{2}=0,524\right)$.

Özetle, araştırma kapsamında test edilen hipotezlerden $\mathrm{H}_{1}, \mathrm{H}_{2}$ ve $\mathrm{H}_{6}$ desteklenmiş, $\mathrm{H}_{3}, \mathrm{H}_{4}$ ve $\mathrm{H}_{5}$ ise kısmen desteklenmiştir.

\section{Sonuç ve Öneriler}

Mobil uygulamalardaki oyunlaştırmanın kabulünün tüketicilerin tutumuna ve kullanım niyetlerine olan etkisinin incelendiği bu 
Tablo 7

Tüketicilerin mobil uygulamalardaki oyunlaştırma kabulünün mobil uygulamalardaki oyunlaştırmaya ilişkin tutumları üzerindeki etkisi

\begin{tabular}{llccccc}
\hline \multirow{2}{*}{ Model B } & \multicolumn{2}{c}{ Standardize Edilmemiş Katsayılar } & Standart Katsayılar & \multirow{2}{*}{ t } & \multirow{2}{*}{ Anlamlılık } \\
\cline { 3 - 5 } & Std. Hata & Beta & & 3,041 &, 003 \\
\hline 1 & (Sabit) &, 427 &, 140 &, 143 & 4,171 &, 000 \\
& Kullanım Kolaylığı &, 165 &, 039 &, 067 & 1,759 &, 079 \\
& Yararlılık &, 064 &, 037 &,- 302 & $-6,421$ &, 000 \\
Eğlenebilirlik &,- 294 &, 046 &, 411 & 9,233 &, 000 \\
Keyif &, 418 &, 045 &, 560 & 11,613 &, 000 \\
\hline
\end{tabular}

a. Bağımlı Değişken: Tutum

çalışmada oyunlaştırmanın hem tüketici tutumlarını hem de kullanım niyetlerini etkilediği saptanmıştır. Çalışmada, mobil uygulamalarda oyunlaştırmanın kabulü, yararlılık, kullanım kolaylığı, keyif, eğlenebilirlik ve sosyallik boyutları itibariyle incelenmiştir. Literatürde, oyunlaştırma ve tutum arasında ilişkileri araştırmak için yapılmış çalışmalarda oyunlaştırmanın tutumu etkilediği görülmektedir. Oyunlaştırma kullanarak laboratuvar dersine yönelik öğrenci tutumlarını inceleyen bir çalışmada oyuna katılan öğrencilerin oyuna katılmayan öğrencilere göre derse karşı daha olumlu bir tutum sergiledikleri görülmüştür (Burkey, Anastasio ve Suresh, 2013). Bittner ve Schipper (2014) tarafından yapılan bir araştırmada, tutumların oyunlaştırılmış ürünlerin satın alma niyetleri için önemli bir belirleyici olduğu saptanmıștır. Bunun yanı sıra oyunlaştırmanın piyano öğrencilerinin teknik egzersiz yapma motivasyonunu etkileyip etkilemediğini ortaya koymayı amaçlayan bir çalışmada ise tutumun oyunlaştırmadan etkilendiği tespit edilmiştir (Birch, 2013). $\mathrm{Bu}$ çalışmada da oyunlaştırmanın tüketici tutumlarını ve kullanım niyetlerini etkilediği saptanmış olup, tüketicilerin tutumunu mobil uygulamalardaki oyunlaştırmanın kullanım kolaylığı, yararlılık, eğlenebilirlik, keyif ve sosyallik boyutları etkilerken, tüketicilerin kullanım niyetlerini mobil uygulamalardaki oyunlaştırmanın kullanım kolaylığı, eğlenebilirlik, keyif ve sosyallik boyutları etkilemektedir.

Oyunlaştırma bağlamında, oyunlaştırılmış hizmete yönelik bir tutum, benzer şekilde,

Tablo 8

Tüketicilerin mobil uygulamalardaki oyunlaştırma kabulünün mobil uygulamalardaki oyunlaştırmaya ilişkin kullanım niyetleri üzerindeki etkisi

\begin{tabular}{llccccc}
\hline \multirow{2}{*}{ Model B } & \multicolumn{2}{c}{ Standardize Edilmemiş Katsayılar } & Standart Katsayılar & \multirow{2}{*}{ t } & \multirow{2}{*}{ Anlamlılık } \\
\cline { 2 - 5 } & Std. Hata & Beta & &, 612 &, 541 \\
\hline $1 \quad$ Sabit) &, 107 &, 175 &, 101 & 2,636 &, 009 \\
& Kullanım Kolaylığı &, 130 &, 049 &, 057 & 1,344 &, 180 \\
Yararlılık &, 061 &, 045 &,- 071 & $-1,344$ &, 180 \\
Eğlenebilirlik &,- 076 &, 057 &, 361 & 7,258 &, 000 \\
Keyif &, 408 &, 056 &, 408 & 7,572 &, 000 \\
Sosyallik &, 482 &, 064 & & &
\end{tabular}

a. Bağımlı Değişken: Kullanım Niyeti 
kullanım amacını etkileyecek şekilde düşünülebilmektedir (Hamari ve Koivisto, 2015). Yani, tutum davranışsal niyetlerin güçlü bir yordayıcısıdır. Literatürdeki çalışmalarda da tutum ve kullanım amaçları arasında güçlü bir ilişki olduğu doğrulanmıştır (Lin ve Bhattacherjee, 2010; Bock, Zmud, Kim ve Lee, 2005; Baker ve White, 2010). Ayrıca, oyunlaştırma kapsamında tutum ve davranışsal niyet arasındaki ilişkiyi araştırmaya yönelik yapılan bir çalışmada da tutum, hizmeti kullanmaya devam etme niyetinin güçlü bir yordayıc1S1 olarak bulunmuştur (Hamari ve Koivisto, 2013). Tüketici inançları, tutumları ve davranış faktörleri, tüketici satın alma niyetini oluşturur ve tüketici satın alma davranışını tahmin etmede önemli bir faktördür (Fishbein ve Ajzen, 1975). Bu çalışmada da mobil uygulamalardaki oyunlaştırmaya ilişkin tutumun mobil uygulamalardaki oyunlaştırmaya ilişkin kulanım niyetini etkilediği saptanmıştır. Tüketicilerin tutumlarının kullanım niyetlerinde belirleyici olduğu göz önünde bulundurularak uygulamacılara özellikle tüketicilere olumlu deneyim sağlayan kullanım kolaylı̆̆ı, keyif, eğlenebilirlik ve sosyallik içeren oyunlaştırma unsurlu mobil uygulamalara yatırım yapmaları önerilmektedir. Bununla beraber mobil uygulama alanlarına oyunlaştırma özellikleri eklenerek sıradan işlemlerin daha keyifli ve eğlenceli hale getirilmesi de mümkündür.

Oyunlaştırma uygulamalarının pazarlama alanında kullanılmasının başlıca hedefleri marka bilinirliğinin, tüketicilerin motivasyonunun ve bağlliklarının artırılmasıdır (Muntean, 2011; Pavlus, 2010; Witt, Scheiner ve Robra-Bissantz, 2011). Bu nedenle, işletmeler hem internet tabanlı hem de mobil tabanlı platformlarda oyunlaştırma unsurlarını kullanmaktadırlar. Bunun yanı sıra, günümüzde tüketicilerin daha bilinçli, teknolojik gelişmelere daha duyarlı oldukları ve bağlılıklarının azaldığı bilinmektedir. Bu bağlamda, çalışmada tüketicilerin yenilikçilikleri ve ilgilenimleri ile mobil uygulamalarda oyunlaştırmanın kabulü arasındaki ilişkiler incelenmiş ve yüksek düzeyde pozitif ilişkiler saptanmıştır. Bu sonuç doğrultusunda uygulamacılara tüketicilerin oyunlaştırmaya ilişkin ilgilenim düzeylerini artırmaları ve yenilikçi tüketicilerin ilgilerini çekmek için cazip ve yenilikçi oyunlaştırma uygulamalarını geliştirmeleri önerilebilir.

Literatür incelendiğinde oyunlaştırma ile ilgili çalışmaların özellikle son yıllarda arttı̆̆ının gözlenmesine rağmen oyunlaştırma kavramının geliştirilmesine ihtiyaç olduğu düşünülmektedir. Mobil uygulamalardaki oyunlaştırmanın kabulünün tüketicilerin satın alma davranışlarına olan etkisini inceleyen bu çalışmanın gerek oyunlaştırma kavramını geliştirmeye katkı sağlayarak literatüre, gerekse uygulamacılara pazarlama stratejilerini geliştirmede yol gösterici olacağına inanılmaktadır.

Mobil uygulamalardaki oyunlaştırmanın kabulünün tüketicilerin tutum ve kullanım niyetlerine olan etkilerini inceleyen bu çaıışmanın bazı kısıtları mevcuttur. Çalışma, sektör fark etmeksizin oyunlaştırma özellikli tüm mobil uygulamaları kullanan tüketicilere uygulanmış olup çalışmanın sonuçları tüketicilerin sadece mobil uygulamalardaki oyunlaştırma kabulü, tutumları ve kullanım niyetleri ile sınırlıdır. Gelecekte yapılacak olan çalışmalara, farklı tüketiciler ve farklı değişkenler dikkate alınarak sektörlerin karşılaştırmalı olarak incelenmesi önerilebilir. 


\section{Kaynakça/References}

Aaker, J. L., \& Lee, A. Y. (2001). "I" seek pleasures and "we" avoid pains: The role of selfregulatory goals in information processing and persuasion. Journal of Consumer Research, 28(1), 33-49.

Agarwal, R., \& Karahanna, E. (2000). Time flies when you're having fun: cognitive absorption and beliefs about information technology usage. MIS Quarterly, 24(4), 665-694.

Ajzen, I. (1991). The theory of planned behavior. Organizational Behavior and Human Decision Processes, 50(2), 179-211.

Ajzen, I. (2005). Attitudes, Personality, and Behavior. McGraw-Hill Education, UK.

Arora, R. (1982). Validation of an SOR model for situation, enduring, and response components of involvement. Journal of Marketing Research, 19(4), 505-516.

Assael, H. (1984). Consumer Behavior and Marketing Action. Kent Pub. Co.

Atkinson, M., \& Kydd, C. (1997). Individual characteristics associated with World Wide Web use: An empirical study of playfulness and motivation. The DATABASE for Advances in Information Systems, 28(2), 53-62.

Baker, R. K., \& White, K. M. (2010). Predicting adolescents' use of social networking sites from an extended theory of planned behaviour perspective. Computers in Human Behavior, 26(6), 1591-1597.

Birch, H. (2013). Motivational effects of gamification of piano instruction and practice. Unpublished Master's Thesis. University of Toronto (Canada).

Bittner, J. V., \& Schipper, J. (2014). Motivational effects and age differences of gamification in product advertising. Journal of Consumer Marketing, 31(5), 391-400.

Blohm, I., \& Leimeister, J.M., (2013). Gamification: Design of IT-based enhancing services for motivational support and behavioral change. Business and Information Systems Engineering, 5, 275-278.
Bock, G.-W., Zmud, R. W., Kim, Y.-G., \& Lee, J.-N. (2005). Behavioral intention formation in knowledge sharing: Examining the roles of extrinsic motivators, social-psychological forces, and organizational climate. MIS Quarterly, 29(1), 87-111.

Bogost, I. (2011, May). Persuasive Games: Exploitationware, Gamasutra: The Art \& Business of Making Games. URL: http://www.gamasutra. com/view/feature/134735/persuasive_games exploitationware.php, 3rd May, 2011 (Ulaşım Tarihi 18.01.17).

Boisvert, J., \& Ashill, N. J. (2011). How brand innovativeness and quality impact attitude toward new service line extensions: the moderating role of consumer involvement. Journal of Services Marketing, 25(7), 517-527.

Bouca, M. (2012). Mobile communication, gamification and ludification. In: Proceedings of the 16th International Academic MindTrek Conference. Presented at MindTrek 2012. ACM, pp. 295-301

Boyle, E., Connolly, T. M., \& Hainey, T. (2011). The role of psychology in understanding the impact of computer games. Entertainment Computing, 2(2), 69-74.

Bunchball, I. (2010). Gamification 101: An introduction to the use of game dynamics to influence behavior. White paper. URL: https://www.csh.rit. edu/ ajman/summer2012/gamification101.pdf (Ulaşım Tarihi: 18.01.2017)

Burke, B. (2014). Gartner redefines gamification. URL: http://blogs.gartner.com/brian_burke/2014/04/04/gartner-redefines-gamification/. (Ulaşım Tarihi: 19.12.2016).

Burkey, D. D., Anastasio, M. D. D., \& Suresh, A (2013). Improving student attitudes toward the capstone laboratory course using gamification. Proceedings of 2013 Annual Conference and Exposition of the American Society for Engineering Education, (pp. 3950-3968). Atlanta, GA: ASEE.

Chau, P. Y. (1996). An empirical assessment of a modified technology acceptance model. $\mathrm{Jo}_{\mathrm{O}}$ urnal of Management Information Systems, 13(2), 185-204. 
Childers, T. L., Carr, C. L., Peck, J., \& Carson, S., (2001). Hedonic and utilitarian motivations for online retail shopping behaviour. Journal of Retailing, 77, 511-535.

Choi, D., \& Kim, J. (2004). Why people continue to play online games: in search of critical design factors to increase customer loyalty to online contents. CyberPsychology and Behaviour, 7(1), 11-24.

Clark, R. A., \& Goldsmith, R. E. (2006). Interpersonal influence and consumer innovativeness. International Journal of Consumer Studies, 30(1), 34-43.

Cowart, K.O., Fox, G.L., \& Wilson, A.E. (2008). A Structural Look at Consumer Innovativeness and Self-Congruence in New Product Purchases. Psychology \& Marketing. 25(12), 1111-1130.

Cunningham, C. \& Zichermann, G. (2011). Gamification by Design: Implementing Game Mechanics in Web and Mobile Apps. O'Reilly Media, Sebastopol, CA.

Davis, F. D. (1989). Information technology perceived usefulness and perceived ease of use. MIS Quarterly, 13(3), 319-340.

Davis, F. D., Bagozzi, R. P., \& Warshaw, P. R. (1989). User acceptance of computer technology: a comparison of two theoretical models. Management Science, 35(8), 982-1003.

Davis, F. D., Bagozzi, R. P., \& Warshaw, P. R. (1992). Extrinsic and intrinsic motivation to use computers in the workplace. Journal of Applied Psycholog, 22(14), 1111-1132.

Deci, E. L., \& Ryan, R. M. (2000). The 'what' and 'why' of goal pursuits: Humanneeds and the self-determination of behavior. Psychological Inquiry, 11(4), 227-268.

Deci, E., Koestner, R., \& Ryan, R. (1999). A metaanalytic review of experimentsexamining the effects of extrinsic rewards on intrinsic motivation. Psychological Bulletin, 125(6), 627-668.

Deterding, S., Dixon, D., Khaled, R., \& Nacke, L., (2011a). From game design elements to gamefulness: defining "gamification". In: Proceedings of the 15th International Academic MindTrek Conference: Envisioning Future Media Environments. ACM, Tampere, Finland, pp. 9-15.
Deterding, S., Khaled, R., Nacke, L.E., \& Dixon, D., (2011b). Gamification: toward a definition. In: Proceedings of the CHI 2011 Gamification Workshop Proceedings. Presented at CHI 2011. ACM, Vancouver, BC.

Domínguez, A., Saenz-de-Navarrete, J., de-Marcos, L., Fernández-Sanz, L., Pagés, C., \& MartínezHerráiz, J.-J. (2013). Gamifying learning experiences: Practical implications and outcomes. Computers and Education, 63, 380-392.

Dubois, D. J., \& Tamburrelli, G. (2013). Understanding gamification mechanisms for software development. In: Proceedings of the 2013 9th Joint Meeting on Foundations of Software Engineering (pp. 659-662). ACM.

Ellis, T. S., \& Webster, R. L. (1999). Innovativeness of information systems managers toward telecommuting: A structural equation model. Journal of Computer Information Systems, 39(3), 92-98.

Festinger, L. (1954). A theory of social comparison processes. Human Relations, 7(2), 117-140.

Filsecker, M., \& Hickey, D. T. (2014). A multilevel analysis of the effects of external rewards on elementary students' motivation, engagement and learning in an educational game. Computers and Education, 75, 136-148.

Fishbein, M., \& Ajzen, I. (1975). Belief, Attitude, Intention and Behaviour: An Introduction to Theory and Research. Reading. MA: Addison-Wesley.

Flatla, D. R., Gutwin, C., Nacke, L. E., Bateman, S., \& Mandryk, R. L. (2011, October). Calibration games: making calibration tasks enjoyable by adding motivating game elements. In: Proceedings of the 24th annual ACM symposium on User interface software and technology (pp. 403-412). ACM.

Gartner Inc. (2014). Gartner Redefines Gamification. http://blogs.gartner.com/brian_burke/2014/04/04/gartner-redefines-gamification/, (Ulaşım Tarihi: 19.12.2016).

Gefen, D., \& Straub, D.W. (1997). Gender differences in the perception and use of email: an extension to the technology acceptance model. MIS Quarterly, 389-400. 
Gerrard, P., Barton Cunningham, J., \& Devlin, J. F. (2006). Why consumers are not using internet banking: a qualitative study. Journal of Services Marketing, 20(3), 160-168.

Goldsmith, R. E., \& Flynn, L. R., (1993). Models of enduring product involvement and opinion leadership in swift", Association of Marketing Theory and Practice Proceedings, 2, 378-386.

Goldsmith, R. E., \& Foxall, G. R. (2003). The measurement of innovativeness. The International Handbook on Innovation, 321-330.

Goldsmith, R. E., Kim, D., Flynn, L. A. \& Kim, W.M. (2005). Price Sensitivity and Innovativeness for Fashion among Korean Consumers. The Journal of Social Psychology, 145 (5), 501-508.

Goldsmith, R., \& Reinecke Flynn, L. (1992). Identifying innovators in consumer product markets. European Journal of Marketing, 26(12), 42-55.

Greenwald, A. G., \& Leavitt, C. (1984). Audience involvement in advertising: Four levels. Journal of Consumer Research, 11(1), 581-592.

Hair, J. F., Black, W. C., Babin, B. J., \& Anderson, R. E. (2010). Multivariate Data Analysis, A Global Perspective. NJ: Pearson, Upper Saddle River.

Hamari, J. (2013). Transforming homo economicus into homo ludens: A field experiment on gamification in a utilitarian peer-to-peer trading service. Electronic Commerce Research and Applications, 12(4), 236-245.

Hamari, J. (2015a in press). Do badges increase user activity? A field experiment on effects of gamification. Computers in Human Behavior. DOI: 10.1016/j.chb.2015.03.036

Hamari, J. (2015b). Why do people buy virtual goods? Attitude towards virtual goodpurchases versus game enjoyment. International Journal of Information Management, 35(3), 299-308.

Hamari, J., \& Koivisto, J. (2015). Why do people use gamification services?. International Journal of Information Management, 35(4), 419-431.

Hamari, J., \& Koivisto, J., (2013). Social motivations to use gamification: An empirical study of gamifying exercise. In Proceedings of the 21st European conference on information systems. Utrecht, Netherlands, June 5-8, 2013.
Hamari, J., Koivisto, J., \& Sarsa, H. (2014). Does gamification work? A literature review of empirical studies on gamification. In Proceedings of the 47th Hawaii international conference on system sciences, (pp. 3025-3034). IEEE. Hawaii, USA, January 6-9, 2014.

He, Y., Chen, Q., \& Alden, D. L. (2016). Time will tell: managing post-purchase changes in brand attitude. Journal of the Academy of Marketing Science, 44(6), 791-805.

Higgins, E. Tory (2006). Value from Hedonic Experience and Engagement. Psychological Review, 113(3), 439-60.

Hirunyawipada, T., \& Paswan, A. K. (2006). Consumer innovativeness and perceived risk: implications for high technology product adoption. $\mathrm{JO}_{\mathrm{O}}$ urnal of Consumer Marketing, 23(4), 182-198.

Hofacker, C. F., De Ruyter, K., Lurie, N. H., Manchanda, P., \& Donaldson, J. (2016). Gamification and mobile marketing effectiveness. Journal of Interactive Marketing, 34, 25-36.

Holzwarth, M., Janiszewski, C., \& Neumann, M. (2006). The influence of avatars on online consumer shopping behavior. Journal of Marketing, 70, 19-36.

Howarth, C. (2006). How social representations of attitudes have informed attitude theories: the consensual and the reified. Theory \& Psychology, 16(5), 691-714.

Huang, J. H., Lee, B. C., \& Hsun Ho, S., (2004). "Consumer attitude toward gray market goods". International Marketing Review, 21(6), 598-614.

Huotari, K., \& Hamari, J. (2012). Defining gamification - A service marketing perspective. In Proceedings of the 16th international academic MindTrek conference. Tampere, Finland, 3-5 October, 2012, (pp. 17-22).

Igbaria, M., Guimaraes, T., \& Davis, G. B. (1995). Testing the determinants of microcomputer usage via a structural equation model. Journal of Management Information Systems, 11(4), 87-114.

Igbaria, M., Iivari, J., \& Maragahh, H. (1995). Why do individuals use computer technology? A Finnish case study. Information and Management, 29(5), 227-238. 
Im, S., Bayus, B.L. \& Mason, C.H. (2003). An empirical study of innate consumer innovativeness, personal characteristics, and new-product adoption behavior. Journal of the Academy of Marketing Science, 31 (1), 61-73.

Jung, J. H., Schneider, C., \& Valacich, J. (2010). Enhancing the motivational affordance of information systems: The effects of real-time performance feedback and goal setting in group collaboration environments. Management Science, 56(4), 724-742.

Kanter, R. M. (1983). The Change Masters: Innovation and Productivity in American Corporations. New York: Simon and Schuster.

Kim, B. D., Shi, M., \& Srinivasan, K. (2001). Reward programs and tacit collusion. Marketing Science, 20(2), 99-120.

Konzack, L. (2007). Rhetorics of computer and video game research. JP Williams and JH Smith (Eds..), The players' realm: Studies on the culture of video games and gaming, (pp.110-130).

Koufaris, M. (2002). Applying the technology acceptance model and flow theory to online consumer behaviour. Information Systems Research, 13(2), 205-223.

Krugman, H. E. (1965). The impact of television advertising: Learning without involvement. Public Opinion Quarterly, 29(3), 349-356.

Kurtuluş, K. (2010). Araştırma Yöntemleri. İstanbul: Türkmen Kitabevi.

Lewinski, J. S. (2000). Developer's Guide to Computer Game Design. Portland: Wordware Publishing Inc.

Lieberman, J. N. (1977). Playfulness: Its Relationship to Imagination and Creativity. NewYork: Academic Press.

Lin, C. P., \& Bhattacherjee, A. (2010). Extending technology usage models to interactive hedonic technologies: a theoretical model and empirical test. Information Systems Journal, 20(2), 163-181.

Mäntymäki, M., \& Riemer, K. (2014). Digital natives in social virtual worlds: A multi-method study of gratifications and social influences in
Habbo Hotel. International Journal of Information Management, 34(2), 210-220.

Martocchio, J. J., \& Webster, J. (1992). Effects of feedback and cognitive playfulness onperformance in microcomputer software training. Personnel Psychology, 45(3), 553-578.

McGonigal, J. (2011). Reality is Broken: Why Games Make Us Better and How They Can Change the World. New York: Vintage.

Midgley, D. F., \& Dowling, G. R. (1993). A longitudinal study of product form innovation: the interaction between predispositions and social messages. Journal of Consumer Research, 19(4), 611-625.

Mitchell, A. A. (1979). Involvement: a Potentially Important Mediator of Consumer Behavior. ACR North American Advances.

Moon, J. W., \& Kim, Y.-G. (2001). Extending the TAM for a World-Wide-Web context. Information and Management, 38(4), 217-230.

Moon, Y. (2000). Intimate exchanges: using computers to elicit self-disclosure from consumers Journal of Consumer Research, 26(4), 323-339.

Muntean, C. I. (2011, October). Raising engagement in e-learning through gamification. In Proc. 6th International Conference on Virtual Learning ICVL (pp. 323-329).

Nass, C. I., Moon, Y., Morkes, J., Kim, E., \& Fogg, B. J. (1997). Computers are social actors: a review of current research. In B. Friedman (Ed.), Human Values and the Design of Computer Technology. Stanford, CA: CSLI Publications.

Nicholson, S. (2012). A User-centered Theoretical Framework for Meaningful Gamification. In Games learning society 8.0, Madison, WI.

Okumuş, A. (2013). Tüketici Davranışı. Türkmen Kitabevi, İstanbul.

Park, H. J., Davis Burns, L., \& Rabolt, N. J. (2007). Fashion innovativeness, materialism, and attitude toward purchasing foreign fashion goods online across national borders: The moderating effect of internet innovativeness. $\mathrm{JO}_{\mathrm{O}}$ urnal of Fashion Marketing and Management: An International Journal, 11(2), 201-214. 
Pavlus, J. (2010). The game of life. Scientific American, 303(6), 43-44.

Perry, E. L., \& Ballou, D. J. (1997). The role of work, play, and fun in microcom-puter software training. The DATA BASE for Advances in Information Systems, 28(2), 93-112.

Petty, R. E., \& Cacioppo, J. T. (1981). Issue Involvement as a Moderator of the Effects on Attitude of Advertising Content and Context. ACR North American Advances.

Puccinelli, Nancy M. (2006). Putting your best face forward: The impact of customer mood on salesperson evaluation. Journal of Consumer Psychology, 16(2), 156-62.

Puleston, J., \& Sleep, D. (2011). The game experiments: researching how gaming techniques can be used to improve the quality of feedback from online research. Proc. ESOMAR Congress 2011.

Ramayah, T., \& Ignatius, J. (2005). Impact of perceived usefulness, perceived ease of use and perceived enjoyment on intention to shop online. ICFAI Journal of Systems Management (IJSM), 3(3), 36-51.

Ramayah, T., \& Lo, M.-C. (2007). Impact of shared beliefs on "perceived usefulness" and "ease of use" in the implementation of an enterprise resource planning system. Management Research News, 30(6), 420-431.

Robertson, M. (2010). Can't play, won't play. Hide and Seek. URL: /http://hideandseek. net/2010/10/06/cant-play-wont-play/ (Ulaşım Tarihi 18.01.17).

Robertson, T. S. (1976). Low-commitment consumer behavior. Journal of Advertising Research, $16,19-24$.

Rodrigues, L. F., Costa, C. J., \& Oliveira, A. (2016). Gamification: A framework for designing software in e-banking. Computers in $\mathrm{Hu}$ man Behavior, 62, 620-634.

Rogers, E. M. (2003). The Diffusion of Innovation. 5th Edition. New York: Free Press

Ryan, R. M., Rigby, C. S., \& Przybylski, A. (2006). The motivational pull of video games: A self- determination theory approach. Motivation and Emotion, 30(4), 344-360.

Sanayei, A., Shahin, A., \& Taherfar, A. (2013). Analyzing the effects of brand innovativeness on attitude towards the brand considering the moderating role of consumer innovativeness with a case study in students of university of Isfahan. International Journal of Academic Research in Accounting, Finance and Management Sciences, 3(3), 290-297.

Seaborn, K., \& Fels, D. I. (2015). Gamification in theory and action: A survey. International Journal of Human-Computer Studies, 74, 14-31.

Seock, Y. K., \& Norton, M. (2007). Attitude toward internet web sites, online information search, and channel choices for purchasing. $J_{O}$ urnal of Fashion Marketing and Management: An International Journal, 11(4), 571-586.

Sherif, M., \& Cantril, H. (1947). The Psychology of Ego-involvements: Social Attitudes and Identifications. New York: John Wiley \& Sons, Inc.

Smith, A. D. (2004). Information exchanges associated with Internet travel marketplaces. Online Information Review, 28(4), 292-300.

Song, Y., \& Han, J. (2009). Is enjoyment important? an empirical research on the impact of perceive enjoyment on adoption of new technology. In Information management, innovation management and Industrial Engineering, 2009 International Conference on (Vol. 4, pp. 511-514) IEEE.

Spears, N., \& Singh, S. N. (2004). Measuring attitude toward the brand and purchase intentions. Journal of Current Issues \& Research in Advertising, 26(2), 53-66.

Steenkamp, J. B. E., Hofstede, F. T., \& Wedel, M. (1999). A cross-national investigation into the individual and national cultural antecedents of consumer innovativeness. The Journal of Marketing, 55-69.

Sweetser, P., \& Wyeth, P. (2005). GameFlow: a model for evaluating player enjoyment in games. Computers in Entertainment (CIE), 3(3), 1-24. 
Tellis, G. J., Yin, E. \& Bell, S. (2009). Global Consumer Innovativeness: Cross-Country Differences and Demographic Commonalities. Journal of International Marketing, 17 (2), 1-22.

Teo, T., \& Noyes, J. (2011). An assessment of the influence of perceived enjoyment and attitude on the intention to use technology among pre-service teachers: a structural equation modeling approach. Computers and Education, 57(2), 1645-1653.

Till, B. D., \& Busler, M. (2000). The match-up hypothesis: Physical attractiveness, expertise, and the role of fit on brand attitude, purchase intent and brand beliefs. Journal of Advertising, 29(3), 1-13.

TÜSİAD, (2017). Dijitalleşen Dünyada Ekonominin İtici Gücü: E-Ticaret. Yayın No: TÜSİAD-T/2017, 04-587, Nisan 2017, İstanbul.

Van der Heijden, H. (2004). User acceptance of hedonic information systems. MIS Quarterly, 28(4), 695-704.

Venkatesh, V. (1999). Creating favorable user perceptions: Exploring the role ofintrinsic motivation. MIS Quarterly, 23(2), 239-260.

Venkatesh, V. (2000). Determinants of perceived ease of use: integrating control, intrinsic motivation, and emotion into the technology acceptance model. Information Systems Research, 11(4), 342-365.

Venkatesh, V., \& Morris, M. G. (2000). Why don't men ever stop to ask for directions? Gender, social influence, and their role in technology acceptance and usage behaviour. MIS Quarterly, 24(1), 115-139.

Venkatesh, V., Thong, J. Y., \& Xu, X. (2012). Consumer Acceptance and Use of Information Technology: Extending the Unified Theory of Acceptance andUse of Technology. MIS Quarterly, 36(1), 157-78.

Von Ahn, L., \& Dabbish, L. (2008). Designing games with a purpose. Communications of the $A C M$, 51(8), 58-67.

Wakefield, R. L., Wakefield, K. L., Baker, J., \& Wang, L. C. (2011). How website socialness leads to website use. European Journal of Information Systems, 20(1), 118-132.
Wang, L. C., Baker, J., Wagner, J. A., \& Wakefield, K. (2007). Can a retail web site be social?. Journal of Marketing, 71(3), 143-157.

Webster, J., \& Martocchio, J. J. (1992). Microcomputer playfulness: Development ofa measure with workplace implications. MIS Quarterly, 16(2), 201-226.

Werbach, K. (2014, May). (Re)defining gamification: A process approach. In International Conference on Persuasive Technology (pp. 266-272). Springer International Publishing.

Werbach, K., \& Hunter, D. (2012). For the win: How game thinking can revolutionize your business. Wharton Digital Press, Philadelphia, PA

Witt, M., Scheiner, C., \& Robra-Bissantz, S. (2011). Gamification of online idea competitions: insights from an explorative case. In: Proceedings of INFORMATIK 2011 - Informatik Schafft Communities, Lecture Notes in Informatics. Presented at INFORMATIK 2011. Berlin, Germany, p. 192

Wu, J., \& Liu, D. (2007). The effects of trust and enjoyment on intention to play online games. Journal of Electronic Commerce Research, 8(2), 128-140.

Yang, J., Cheng, L., \& Luo, X. (2009). A comparative study on e-banking services between China and USA. International Journal of Electronic Finance, 3(3), 235-252.

Yoon, C. (2009). The effects of national culture values on consumer acceptance of e-Commerce: online shoppers in China. Information Management, 46(5), 294-301.

Zaichkowsky, J. L. (1986). Conceptualizing involvement. Journal of Advertising, 15(2), 4-34.

Zaichkowsky, J. L. (1994). The personal involvement inventory: Reduction, revision, and application to advertising. Journal of Advertising, 23(4), 59-70.

Zichermann, G., \& Cunningham, C. (2011). Gamification by Design: Implementing Game Mechanics in Web and Mobile Apps. O'Reilly Media, Inc.

Zichermann, G., \& Linder, J. (2010). Game Based Marketing: Inspire Customer Loyalty Through Rewards, Challenges, and Contests. John Wiley and Sons. 